\title{
Landscape Design to Meet the Societal Demand for Ecosystem Services: A Perspective
}

\author{
Bjoke Carron ${ }^{1, *}$, Bart Muys $^{2}$, Jos Van Orshoven ${ }^{2}$ and Hans Leinfelder ${ }^{1}$ \\ ${ }^{1}$ Department of Architecture, KU Leuven, Ghent, Belgium \\ ${ }^{2}$ Department of Earth \& Environmental Sciences, KU Leuven, Leuven, Belgium \\ * Corresponding author: bjoke.carron@kuleuven.be; Tel.: + 3292251000
}

Submitted: 15 January 2021 | In revised form: 16 April 2021 | Accepted: 10 May 2021 |

Published: 14 September 2021

\begin{abstract}
In recent decades, the concept of Ecosystem Services (ES) has generated a paradigm shift in the perspective of human society on nature and has had an important awareness-raising role concerning the importance of ecosystems. However, the concept has not been capable to stop the loss of biodiversity and nature in order to meet the societal challenges of ES provision, especially in urbanized territories. From the reviewed literature, it is obvious that implementing the ES concept within spatial design and planning processes poses several difficulties. In this context we state that a more comprehensive approach is needed of which the ES concept is part. To move to genuine landscape change and a shift in land use and land stewardship, we argue that a landscape design approach can play a significant activating role. The goal of this paper is to underpin this assumption from a theoretical and methodological point of view. The paper first gives an overview of the difficulties that the field of ES science and practice is facing when implementing the ES concept in landscape design and planning processes. Then a landscape design approach is presented as an alternative approach and a possible way forward for genuine landscape change to meet the societal demand for ES (Fig. 1).
\end{abstract}

Keywords: Ecosystem services cascade; Ecosystem services critique; Landscape change; Landscape design and planning; Research through design 


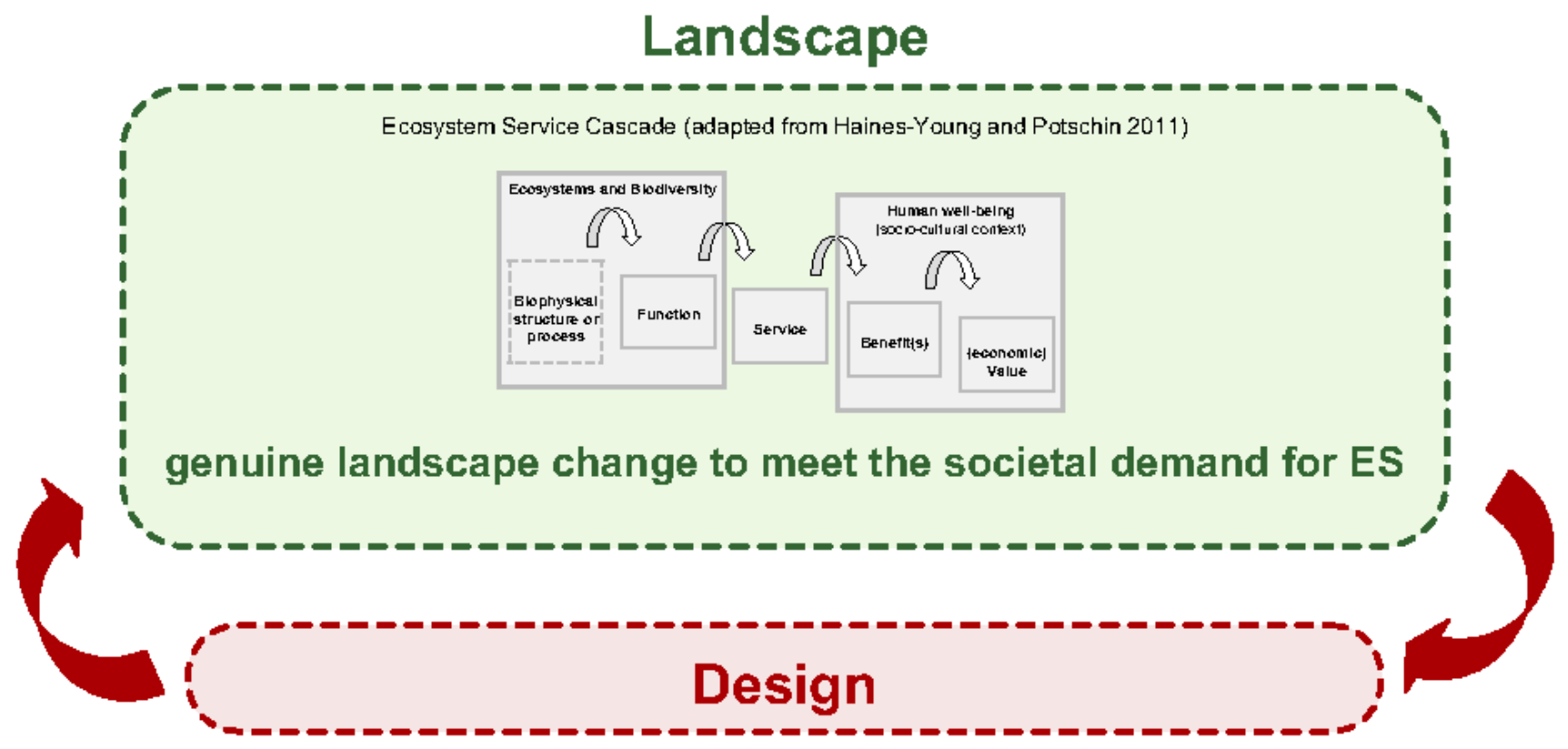

Figure 1. Graphical Abstract.

\section{Introduction}

The concept of ecosystem services (ES in the remainder of this paper) has been developed to integrate ecological concerns and economic thinking in an attempt to redress the neglect of biodiversity and nature in policy, through translating the value of ecosystems in a language and approach that fits within the dominant political and economic discourse [1,2]. As Costanza et al. ([3], p. 253) bluntly start their seminal publication: "Because ecosystem services are not fully 'captured' in commercial markets or adequately quantified in terms comparable with economic services and manufactured capital, they are often given too little weight in policy decisions."

In the last two decades, the concept of ES has gained impressive scientific and political resonance. Since the publication of the Millennium Ecosystem Assessment [4] and enforced by the Economics of Ecosystems and Biodiversity report [5] and the establishment of the Intergovernmental Platform on Biodiversity and Ecosystem Services [6,7], ES scientists have concentrated their efforts on understanding the complexity of ecosystems and their interaction with human societies with respect to the benefits these natural ecosystems can supply. In recent decades, many initiatives are taken both at the methodological level, framing core concepts and approaches, as well as at the operational level (see www.es-partnership.org for a broad overview). Initiatives are taken to assess, map, quantify and value ES as well as to apply the ES concept to real-world situations, in case studies in the fields of planning, policy and management [8-17].

More recently, the concepts of Green Infrastructure (GI) $[18,19]$ and Nature Based Solutions (NBS) $[12,20]$ were introduced in an attempt to make the ES concept more applicable. Gl can be defined as a "strategically planned network of natural and semi-natural areas with other environmental features designed and managed to deliver a wide range of ecosystem services" ([21], p. 3) and NBS as "solutions that are inspired and supported by nature, which are cost-effective, simultaneously provide environmental, social and economic benefits and help build resilience" ([22], p. 1). Whereas Gl emphasize the spatial character of natural networks, NBS have a strong problem solving focus. Escobedo et al. [23] depict ES, Gl and NBS more as evolving and 'snowballing' metaphors.

Nowadays, ES are considered as the key concept to make values of natural ecosystems explicit. Both the concept of ES and the subsequent cascade model [24] provide a framework to look at the linkages between people and ecosystems, to understand causal dependencies between human activities and their impacts on the natural environment, which has been identified as a major challenge within the contemporary society [6]. The concept of ES made a paradigm shift in the perspective of human society on nature and has had an important awareness-raising role concerning the importance of ecosystems [25].

Albert et al. [26] conclude in their review of papers on case studies in which the ES concept is integrated in landscape planning that the added value of the ES concept is 1) the provision of knowledge, and 2) the contribution to cooperative planning and implementation (through communicating the contributions and values of ecosystems), and 3) the impact of planning alternatives on these contributions. Stakeholders of the OpenNESS project highlight amongst others, the following advantages of the ES cascade framework: 1) strengthening communication, and 2) developing 
understanding [27]. A conceptual framework such as the cascade framework, can help to provide structure in complex relationships and highlight different components and interlinkages. An assessment of the case studies of the OpenNESS project by Saarikoski et al. [14] concludes that ES knowledge was used conceptually to alter beliefs and understanding about the role of ecosystems for human wellbeing, and strategically to help stakeholders articulate their interests and concerns.

However, despite the attempts to improve the implementation of the ES concept, there is still a large gap between the vast body of quite technical academic research on ES and the implementation in a spatial context [27], in particular in an urbanized environment [28]. The operationalization of the concept, i.e. putting it into practice, is still considered a challenge [29]. The premise in the MEA [4], TEEB [5] and other seminal works on ES (e.g. Braat and de Groot [8]; de Groot et al. [30]; Maes et al. [31]) that knowledge of ES and their valuation in economic terms can be used to influence policy decision-making to stop the loss of biodiversity and nature, has not yet been achieved [14,32,33]. Within the ES community, there is a limited body of evidence that ES studies or interventions yield impact [34] and the debate about the conditions in which new knowledge is or is not used, by whom and for what purpose, has barely begun [35]. Significant in this regard is the description in ES science of the complicatedness of the real world (where things happen) as 'messy' and spatial problems as 'wicked' problems [27].

To improve our living environment, design and planning are crucial steps $[30,36,37]$. However, implementing the ES concept within spatial design and planning processes poses several difficulties and both researchers and practitioners are still looking how the concept can be applied $[27,38]$.

In this paper we summarize the difficulties that the field of ES science and practice is facing when implementing the ES concept in landscape design and planning processes. These difficulties are the arguments to come up with a landscape design approach, which provides an alternative approach and possible way forward to stop the loss of biodiversity and nature, and to come to genuine landscape change in order to meet the societal demand for ES.

\section{Difficulties to Use the Concept of Ecosystem Services from the Perspective of Landscape Planning and Design}

The difficulties that the field of ES science and practice is facing when implementing the ES concept in landscape design and planning processes have been addressed before, but-to our knowledge-never together in an exhaustive way. Moreover this has been done mostly from a scientific point of view (how the ES concept is used) and rarely from the perspective of the design and planning practice on the landscape scale (how the ES concept can be used). We address five crucial issues, being: 1) the concept is a limited conception why nature matters, 2) it has little meaning to local communities, 3 ) it struggles to capture the complexity of a coupled social-ecological system, 4) it fails to capture the 'whole' of the landscape, and 5) there is no attention to spatial and temporal dimensions.

\subsection{Limited Conception Why Nature Matters}

The ES concept was initially constructed to bring economy closer together with ecology by employing economic language ('goods and services') and a utilitarian logic (valuation of 'benefits' for humans) [3,39,40].

As an eco-economic construct, the ES concept frames the world in a particular way and communicates a specific view on human-nature relationships. The notion 'service' expresses an instrumental, anthropocentric slant and mercantile relationship. Although couched in the language of scientific certainty, the concept emphasizes the dominant discourse of nature as an instrument to human wellbeing and as a resource to be (more) efficiently managed. The ES concept became a cornerstone for environmental and nature management, and so, the strong focus on benefits human obtain from ecosystems may advocate an approach driven by a gospel of eco-efficiency and a strong problem solving character $[23,27,41]$. Although ES research has progressed beyond a mere economic and ecological perspective $[42,43]$, the instrumental framing of nature remains evident through the use of the notion 'service' and focus on valuation.

This instrumental framing of nature as a source of human benefits, is a quite limited conception why nature matters. This critique also remains when replacing ecosystems with landscape, in the concept 'landscape services' as proposed by Termorshuizen et al. [44]. The ES concept is only one out of many possible ways of framing human-nature interactions [41]. Human-nature relationships are highly diverse and complex. Nature and its contributions to society are often perceived and valued by people in starkly different, often conflicting ways $[45,46]$. This makes the valuation of ES highly context dependent both in space and time [47], which also effects the question of valuation regarding future generations [48].

In ES assessments, most often biophysical and monetary values seem to prevail, and non-material or inherent values are kept out of the equation $[16,49,50]$. However, there is often no direct use of services (i.e. pollination) or there may be a non-consumptive use (i.e. air quality regulation). Multiple values can be attached to one particular service or benefit, and it is the combination of all values that influences human use of ecosystems. Many of the 'underlying values' are those that shape people's perception of the world and guide their decisions and actions [51].

Recently, there is a growing attention to put people's values more central in ES science [52,53]. For example, the IPBES presents Nature's Contribution to People (NCP) as a broader concept than ES, focusing more on the importance of culture to understand the relationship between nature and people [54]. It has also been recognized that there is a need to combine a range and variety of disciplines and methods to represent these diverse values of nature 
[55-57]. To encompass also cultural or 'shared' services, deliberative and participatory methods are increasingly being advocated [58,59] (see also 2.2.).

\subsection{Little Meaning to Local Communities}

Many ES assessments are based on datasets that mainly rely on biophysical attributes such as land cover or land use variables [60,61]. Martínez-Harms and Balvanera [62] found that the main data used to map ES supply were land cover variables for all four ES categories (supporting, regulating, provisioning and cultural ES). Because land cover or land use variables are only one aspect of ecosystems, these variables are just proxy indicators. These proxy indicators, often on larger (national or regional) scales, have a high degree of abstraction and the context is excluded.

Ecosystems are always embedded in a spatial context, related to specific physical spaces and social-cultural places, and manifest themselves as perceptible landscape elements. For example, the ES provided by a street tree are different to the services provided by a similar tree in a park or forest. Political ecologists have built strong critiques on how (economic) conceptions of nature abstract it from its spatial and social context [41]. Due to this lack of particularity, the ES concept has little meaning to local communities and practitioners, to those who live and work in the landscape [44]. The ES concept was found to be too abstract to attach to for people and too difficult to understand [14]. As Potschin and Haines-Young [63] put it 'context matters' and ES have to be considered in the context of 'place'.

The use of proxy indicators (such as land cover types) and linking them to generic estimates of values, result in maps that are very generalized with little spatial detail [64]. Although they may be suitable for identifying broad-scale trends in ES and can be helpful in creating policy awareness [60], proxy indicators are simplistic and insufficient as they miss the much needed particularity for planning and design at the local scale.

Recently, there is a growing attention for both expert knowledge and local approaches, involving (local) experts and stakeholders in ES research $[10,65]$. In different ES case studies, the authors conclude that stakeholders should be put in the centre of the approach [53] to be more 'actionable' for practitioners $[13,33]$. Knowledge co-production through for example action research or participatory scenario analysis has been mentioned as an enabling factor in the use of ES information [14]. The case study described by Ruiz-Frau et al. [66] illustrates how a focus on place can be effective in identifying the multiple benefits that ecosystems provide. Pocock et al. [67] state that visualization is an important tool for communication and engagement. Andersson et al. [68] suggest the use of cultural ES as a gateway for addressing and managing ES. The daily experience of cultural ES through the interactions with (urban) ecosystems makes them easier to relate to and meaningful to people in ways that other ES may not. Carmen et al. [57] note that transdisciplinary research approaches are seen as a promising way forward to develop more collaborative practices.

\subsection{Struggling to Capture the Complexity of a Social-Ecological System}

Within the ES concept, nature and people are represented as separate objects, with a distinct directional flow of benefits from the former to the latter. 'Ecosystems' refer to a non-human nature that supplies 'services' to the society [41]. This decoupling of natural and social dimensions creates a problematic friction when using the ES concept in the landscape planning and design practice.

In most places all over the world, it is no longer about 'pristine' nature but about ecosystems that are co-produced to various extents by humans $[69,70]$, pluralized configurations in which social and biophysical features are intertwined. Especially in urbanized areas, natural and social features are inextricably interlinked to form closely intertwined systems with dynamic interactions [71,72]. The result is a land use pattern with a unique multifunctionality [73], fuzzy borders and interfaces between urban, peri/semi-/sub-urban, agricultural and natural areas [74]. In such urbanized areas, ecosystems cannot only deliver provisioning ES without cultural ES.

Due to the decoupling of natural and social dimensions of an inherent coupled social-ecological system, the ES concept struggles to capture the 'messy' and 'wicked' complexity. A study of ES trade-off cases by Turkelboom et al. [53] features a complexity that is far greater than what is often described in the (theoretical) ES literature. A lot of studies acknowledge that ES are the result of the interaction of ecological processes and human influences (input, accessibility etc.) (see e.g. Reyers et al. [75]), but a comprehensive approach to capture the complexity of coupled social-ecological systems and identifying underlying mechanisms is still lacking $[76,77]$.

\subsection{Failing to Capture the 'Whole'}

Ecosystems provide a multitude of services, yet the need for quantification and data results in a methodology to address only a small selection of them [78]. One of the consequences of assessing ES is the limitation to and "cherry picking' of services with the most available or measurable data on indicators [41]. Many studies within the field of ES assessment and implementation are based on secondary (existing) data that are readily available from external sources [61,62]. Quantifiable measures are because of their nature more appropriate for specific kinds of services or indicators than others, for example timber production as an indicator for the provisioning services of forests as a whole. This means that many studies focus on only a few ES $[61,79]$ and the more accountable ES [59], which means that relevant values may not be captured $[80,81]$.

However, analysing only a few ES or certain indicators instead of others can fundamentally change the outcome 
[77,82]. Martínez-Harms and Balvanera [62] note that regulating services are the most commonly mapped services (see also Kieslich et al. [16]. Cultural ES remain often invisible because they are intangible, subjective and often have no material benefit. Therefore, they are difficult to quantify and are poorly studied [83]. Although novel methods are developed to assess socio-cultural values (e.g. Scholte et al. [84], intellectual or spiritual interactions with ecosystems remain difficult to quantify compared to regulating or provisioning services [43].

Also involving certain stakeholders (and others not) and taking their values as base for further planning or valuation is problematic as well and encompasses the risk of overlooking other ES. Stakeholders are not always aware about the contributions of ecosystems or don't have access to information on these ES because they are not directly affected in the short term or they are focused on only one benefit [85]. One of the findings of Dendoncker et al. [33]was that highly valued ES are among the most visible in the landscape and are actively and purposely used.

Many authors have recognized the need to assess ES associations (see e.g. Jacobs et al. [56]; Spake et al. [86]). Not only targeted ES should be considered, but also impacted ES [53]. Some services may spatially co-occur (ES bundles) ensuring synergies, while other services involve trade-offs $[87,88]$. By addressing single services in isolation, the concept of ES fails to capture the 'whole' of a complex social-ecological reality $[89,90]$, leading to limited and fragmented outcomes that form a very narrow basis for planning and design. Disentangling the complexity of ES to make them explicit and to be able to value them, has prevented a holistic approach [91].

\subsection{No Attention to Spatial and Temporal Dimensions}

Many ES assessments start from datasets at regional or national scale and mix data from several scales, whereas very few ES mapping studies are done at the patch or local landscape scale [62]. In addition to this, the most common approach is to take a snapshot at a single moment in time [92,93].

However, ecosystems are always embedded in a particular geographical area, manifest themselves as spatial landscape elements and are dynamic through time and space. Both social and environmental drivers operate and interact at different scales and at different speeds [83,94]. Therefore, it is important to understand the dimensions of ES interactions, in space and at different scales, as well as in time and different historical periods. Especially in urbanized territories, ecosystems are locally embedded in historically specific social practices.

There is an intricate relationship between the spatial properties of ecosystems or landscape elements, the diversity of land use opportunities that they generate and thus the provision of services. Different ES can depend either on the properties of an element, or on the spatial configuration of elements and the effects caused by the interactions within a larger landscape or at different scales [89]. Depending on the spatial scale, both the functioning of ecosystems as well as the relationships between ecosystems and their beneficiaries (the demand, use and supply of services) can vary. Small et al. [83] found that the sum of aggregated individual values does not necessarily correspond to the values of a group or society at larger scales. For example, although people know of the societal value of woodlands for climate regulation at the global scale, most are likely to value it for nearby recreational outdoor activities.

Ecosystems undergo also changes because of seasonal changes as well as because of dynamics in landscape history. Both ecosystem structures and processes change due to natural or human-induced processes (e.g. succession or land-use), and demands for ES change (because of population dynamics, preferences, technological innovation, social-economic changes, etc.). Recent studies have shown that legacies from landscape history play a critical role in current ES provision [95,96], that interactions among ES (trade-offs and synergies) changed across both time and space [93] as well as preferences for certain ES [97]. Renard et al. [93] found that the provision of ES increased through time and that trajectories of change were not uniform but related to the spatial context. Bürgi et al. [97] found that cultural ES gained in importance over time, that education and hydropower were 'new' ES (in 2010) and that regulating and supporting ES are there also when society is not aware of them.

This means that ignoring the spatial and temporal dimensions of ecosystems may affect conclusions about ES. Eigenbrod et al. [98] show that, specifically when applied at the local scale, methods based solely on land cover data can have strong errors. Mixing scales, both the up- and down-scaling of data (e.g. re-sampling down from lower resolution data, or aggregating from higher resolution data) can lead to oversimplification and an incremental number of inaccuracies, which may affect the validity of the outcomes (see e.g. Ottoy et al. [99]). Potschin and Haines-Young [63]conclude that 'boundary' and 'scale' problems are common to many ES assessments and among the most difficult to solve, whereas Mulder et al. [100] conclude that most of the research priorities they defined concern spatial and temporal dimensions.

There seems to be an increasing attention for both the spatial and temporal dimensions of ES and more accuracy in assessments. A 'full' assessment of ES needs a multidimensional approach as the assessment of systems simultaneously at different scales is a key element of 'complexity thinking' [101], and the temporal dynamics in demand and preferences for ES over time does pose a great challenge regarding to future generations [48].

Different researchers advocate to geographically localize potential, flow and demand of ES as well as temporal demand and supply dynamics such as seasonal aspects [102], to identify spatial hotspots [103], to distinguish 'service providing areas' and 'service benefiting areas' [104], to encompass individual and community values across scales 
and time [83], to start from service providing units (SPU) [105]. To consider the potential effects of social-ecological drivers of change on an ecosystem, scenario approaches where plausible changes are investigated through models linking land use change to ES delivery, are seen as promising avenue $[27,83]$.

\subsection{Conclusion Regarding the Difficulties}

The ES concept is only one out of many possible ways to frame human-nature interactions. However, human-nature relationships are highly complex and diverse, and people value nature often in starkly different ways. Due to the high degree of abstraction and lack of spatial particularity, the ES concept has little meaning to local communities. In particular in urbanized territories, disentangling the complexity of ES hampers a holistic approach to capture the 'whole', the 'messy' and 'wicked' complexity of a coupled social-ecological system in space and time.

Instead of trying to fully understand all single aspects of a complex social-ecological system, another approach is needed to stop the loss of biodiversity and nature. Especially in urbanized territories, environmental change is not just a technical phenomenon and approaches based on merely (scientific) knowledge are often inadequate to propel change $[106,107]$. A more comprehensive approach is needed of which the ES concept is part. An approach that goes beyond theory and conceptualization, and better connects with the scale and complexity of the human living environment where landscape change occurs. To move from agendas, scientific knowledge, theories and models to come to genuine landscape change, there is a need for:

- A holistic, transdisciplinary approach to capture the 'whole' and the complexity of the coupled humannature system in space and time, in particular in urbanized territories;

- Knowledge co-production and a contextualized approach that is more meaningful to people;

- A transformative approach towards a reconceptualization of how to inhabit the planet and how to activate for change.

\section{Introducing Landscape Design for Landscape Change}

We propose a landscape design approach as a way forward to come to genuine landscape change and a shift in land use and land stewardship in order to meet the societal demand for ES Figure 2.

Ecosystems are always spatially embedded in a landscape, and so does the flow of services to human wellbeing. Yet, landscapes are both naturally constituted entities as well as socio-culturally shaped. They are not a fixed state of the art or ontologically pre-given, and thus can be shaped and designed. Design can be considered as an ontological force to understand and to make the world [37], as it can steer the functioning and appearance of the environment in which we live, to a greater or lesser extent. We can thus state that new concepts for how to inhabit the planet, for a desirable future and to activate towards change can be considered as a landscape design assignment. Different aspects of 'shaping' can be incorporated within a landscape design process: both the development of visions, plans and projects, as well as policy and decision making, implementation and management.

In the next two sections first the landscape is introduced as the place where ecosystems are spatially embedded and people live ('where it happens'), and then design is introduced as a mode of inquiry to activate change. In the last section, the landscape design approach is further developed through a set of working principles.

\subsection{Landscape: The Place where it Happens}

The awareness is growing that there is a need to look at the planet as one social-ecological system where humanity and ecosystems are entangled and form nested systems instead of separated ones $[36,39,108,109]$. This holistic perspective is coincident with the integrative nature of the concept of landscape $[90,110,111]$. Therefore, we state that the concept of landscape is more apt for capturing the 'whole' and complexity of coupled human-nature systems in a way that is meaningful to people.

Although different definitions of landscape exist, many of them encompass similar characteristics [112-115]:

- Integration of different elements and systems, both natural and human;

- Attention to coherence, relations and interaction, the 'whole';

- Dealing with dynamics, processes and transformation (and thus flexibility and temporality);

- Attention to both the physical reality and the mental significance, value of perception and representation of an area.

Most of these characteristics are included in the definition of the European Landscape Convention: "an area, as perceived by people, whose character is the result of the action and interaction of natural and/or human factors" ([116]: art. 1, a). This definition shows the transition within the meaning of the concept of landscape. Landscape no longer refers solely to traditional rural countryside (in European tradition) or to spectacular nature (in the American tradition) [117]. Landscape has shifted from being a sectoral interest associated with amenity, to a core, integrative concept (enabling the delivery of sustainable development from a multifunctional perspective) and frame for responding to complex future challenges [118]. 


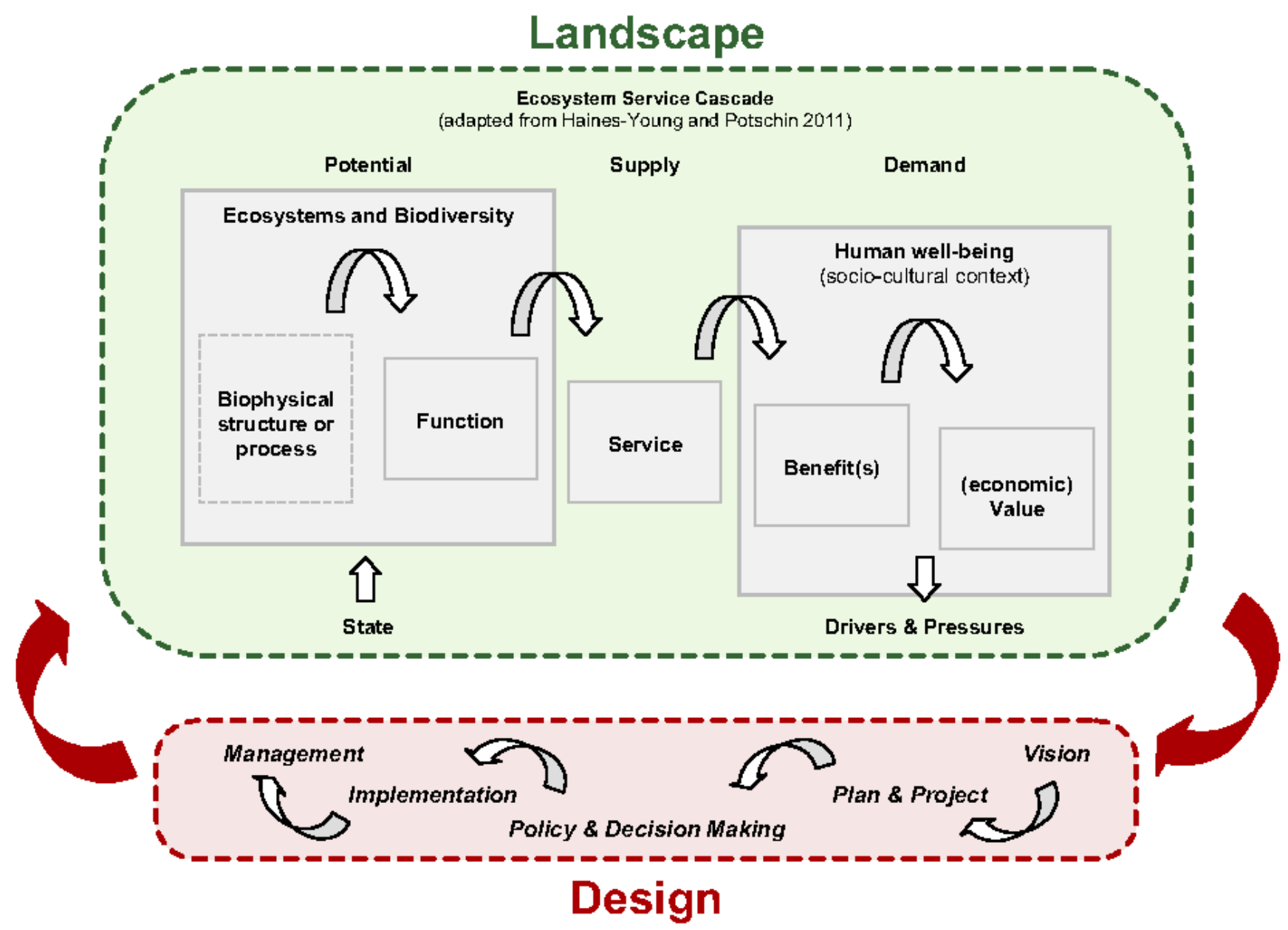

Figure 2. Landscape design for genuine landscape change to meet the societal demand for ES. Landscape as the place where it happens and Design as a mode of inquiry to activate change.

A useful conceptualization of the landscape regarding the concept of ES, is that of spatial social-ecological system (SES). The concept of social-ecological systems emphasises the integration of humans in nature and stresses that the delineation between social systems and ecological systems is artificial and arbitrary [109].

\subsection{Design: Mode of Inquiry to Activate Change}

In the (near) future, important changes can be expected in land cover, and thus in our landscapes [119]. The increasing urbanization [120] together with the growing awareness of the planetary boundaries [121] and the importance of the climate and ecosystems for humanity call for a genuine landscape change and a re-conceptualization of how to inhabit our planet. In this era of increasing systemic transitions, new hypotheses are required regarding the desired human-environment interaction for a more resilient way of land stewardship [122]. As Costanza and Kubiszewski ([36], p. 79) state: "Creating a sustainable and desirable future will require an integrated, systems-level redesign of our cities".

'Design' is both a noun and a verb, an artefact and a process [123]. Design as an artefact is described as the finality of the act of designing in which a product, the design output, is given shape and may be implemented. Design as a process is described as the process of creating design artefacts, and in this way can be considered as a mode of knowledge production. Lenzholzer et al. [124] proposed to use the gerund form-designing - to more clearly distinguish the verb from the noun. Drawing, mapping, visualising, representing, giving shape and repeated analysis and reflection are some of the unique activities that constitute the process of designing.

After a long period of specialization, a new epistemological perspective has been launched that seeks to understand the whole of the mechanism at work (system-oriented) instead of focusing exclusively on fragments and parts (objectoriented) [125]. The hybridization of knowledge production has become a widespread and intensively debated issue within the scientific community. After the introduction of 'designerly ways of knowing' by Nigel Cross [126] and the 'second mode of knowledge production' by Gibbons et al. [127] who both argued that there are forms of knowledge and ways of knowing peculiar to design, Dunin-Woyseth 
and Nilsson [128] proposed 'hybrid forms of knowledge production' in which different practices of research and design are placed next to one another in a continuum. Within the field of landscape architecture, it is Steinitz [129] who gave designing a more prominent role in research.

Research through (or by) design is more and more recognized as a legitimate and sound scientific research method (see for a broad discussion on design knowledge: Rodgers and Yee [130]). The methods and criteria for research quality have been widely discussed (see e.g. Groat and Wang [131]; Stremke and Schnöbel [132]; van De Weijer et al. [133]; van den Brink et al. [134]).

Research through design can be considered as a hybrid mode of knowledge production or mixed-method approach [135], integrating scientific 'rational' knowledge and design-based 'mimetic' ways of knowing [133]. It is a research method that actively employs the act of design(ing) for knowledge inquiry [136-139]. Key characteristics of these 'designerly ways of knowing' are mentioned to be: the wicked, the situated, the experiential, the tacit, the actionable, know-how, the future-oriented, the artefactual, the interdisciplinary and the integrative [140]. The shift towards considering design as a research activity can be done only if both the design (resulting artefact, e.g. concepts or prototypes) and designing (process of creating artefacts) are considered as epistemic tools to produce and share new knowledge [141]. In this paper, research through design is considered as explorative, comprehensive, imaginative and transformative mode of knowledge inquiry that is conceived, related and augmented by means of design.

\section{Working Principles to Operationalize the Landscape Design Approach}

Landscape design can contribute to genuine landscape change in order to meet the societal demand for ES in a number of ways. In the next section we address seven working principles for the operationalization of the approach:

1. Enhancing transdisciplinarity and coherence through a shared spatial reference and focus;

2. Capturing the complexity of a social-ecological system;

3. Operating across scales and starting from the 'meaningful' local scale;

4. Making things visible;

5. Designing with transformation and imagining future landscapes;

6. Applying a deliberative and collaborative process;

7. Knowledge inquiry through design practice.

\subsection{Enhancing Transdisciplinarity and Coherence Through a Shared Reference and Focus}

Although simultaneously perceived and valued in many different ways [142,143], a landscape can serve as a shared reference object. Starting from the landscape offers a spatial context and a focus that is perceptible to different disciplines and stakeholders. In this way, landscape can be a 'boundary concept', plastic enough to adapt to different perspectives, but also robust enough to maintain coherence [144]. Although the 'knowability' (the capability of being known), perception and the appreciation of the landscape can differ, it allows different people to refer to properties of the boundary object that are more or less well-understood by different participants. Employing landscape as boundary concept can facilitate transdisciplinarity and coherence [145].

Both landscape and design research and practice have a longstanding tradition in transdisciplinarity and methodological pluralism $[125,146]$. As a landscape includes both a physical reality and a mental construction (through cultural reading and perception), a landscape approach requires different scientific methods from both the natural sciences (empirical) and the humanities (interpretative) [132]. The combination of the comprehensive nature of the landscape and the merging capacity of design are useful to enhance transdisciplinarity and coherence.

A landscape design approach has the capacity to blend different kinds of information (datasets to local experience), as well as to make (scientific) knowledge spatially explicit, to reframe and exchange different points of view, and to move that exchange towards a shared conception of ideas, decision-making and action $[111,147]$. Looking at representations or walking around on site make it possible to be attached to a shared reference object seen by all. Multiple methods and techniques are being used to gather information, and knowledge of different fields and different perspectives can be linked through methods of transdisciplinary co-design or an interdisciplinary sequential process of research and design.

Because landscape can be a shared spatial reference and focus, a landscape design approach can facilitate to:

- Combine multiple disciplines and methods [55-57];

- Reveal multiple perspectives and values assigned to ES $[46,83]$

- Cross dispersed sectoral objectives (in science, policy, planning and management) and administrative borders [63];

- Come to shared visions, decision-making and actions [111,148].

\subsection{Capturing the Complexity of a Social-Ecological System}

Landscapes are considered as coupled spatial socialecological systems, resulting from the interplay between the physical environment and human actions and perceptions [109]. Different ecological and social processes co-operate in and through the same landscape, so each landscape inherently integrates these processes [149]. This means that the concept of landscape underpins the complexity that arises from the inextricably inter-linked interactions between society and the natural environment, between processes and values related to livelihood and quality of life that are associated with biophysical features. This is especially of major importance 
for urbanized territories [73]. The study of social-ecological systems emphasizes the need for considering this interplay to understand changes in land use [150].

Because a landscape can be perceived as one entity, it can be a conceptual device or medium to capture spatial complexity [111], whereas the capacity of dealing with complexity is one of the main characteristics of design as well. To face the 'messy' and 'wicked' complexity of reality, landscape designers tend to take a dynamic system perspective $[151,152]$. This perspective enables to understand particular elements in interaction with constituent parts, and not isolated [153].

Landscape design methods are used to apply system and network based analyses, and to disentangle the multilayered landscape simultaneously by the same system component or landscape element. As Kempenaar et al. quote "design makes you understand" ([148], p. 27). An example of a conceptual framework to analyze and understand a landscape, is the layers approach where three interrelated layers are distinguished: the substratum, the network and the occupation layer [154]. Through field visits, participation of stakeholders, studying of (historic) maps, GIS analysis, document and literature study, information on the different layers is gathered [152]. The information is often drawn on maps to give it a spatial dimension and to identify correlations. After the dissection and broad understanding of the area, in a next step of the landscape design process, the landscape is reframed $[152,155]$. This reframing enables to identify important issues or critical places, to separate main from secondary issues.

Starting from the landscape and using a landscape design approach can contribute to:

- A more holistic understanding of ES [91], capturing the complexity of a coupled social-ecological system and identifying underlying mechanisms [75-77];

- Assess ES associations or bundles, synergies and trade-offs [86-88];

- Disentangle structures and processes of ecosystems, spatial interactions, drivers and pressures, etc. [110];

- Disentangle without losing the 'whole' of the landscape where ecosystems are part of $[89,90]$.

\subsection{Operating Across Scales and Starting from the 'Meaningful' Local Scale}

There is a growing consensus that sustainability must be achieved at the local level [156] and that the scale of local communities is the key to contribute significantly to landscape change [106]. The local landscape is the living environment of human communities [157]. As a consequence, the landscape at the local scale can be known to its inhabitants, practitioners and policymakers. It is there, at the landscape scale, that we can better see how the global is linked to the local [158]. Because often unnoticed and sometimes invisible natural and societal processes are 'known' and linked with everyday experience at the landscape scale, it is decisive for landscape change [111]. The landscape is the place where local identity and sense of place are been experienced and perceived by people, 'a way to know the world' [159]. This 'perceptible realm' [160] is where humans imagine, negotiate, decide, intervene and manage landscape elements.

Understanding different nested scales and the interaction between them, is a crucial aspect of landscape design. Scale is about size and context, and landscape designers are used to address both smaller and larger spatial scales than the considered object or area itself. Crossing scales is about swaying between the global and the local, a region and ES providing landscape units [161], as well as the position of a region in its context and perspectives related to the human scale [158]. In landscape design, switching from a regional scale to the local, human scale is used to test how ideas work out, but the local scale is also the appropriate scale to connect to local stakeholders [152]. Both vertical relations (linking layers of the landscape) as well as horizontal relations (linking places in the landscape) are integrated.

Crossing scales and starting from the local scale and landscape units in a landscape design approach, has the advantage of:

- Assessing systems simultaneously at different scales [83,94,101];

- Contextualize ES and link it to a place where people can relate to $[63,66]$;

- Achieving more spatial detail $[64,98,105]$;

- Geographically localizing demand and supply dynamics of ES [102-104];

- Incorporating informal and tacit information from local stakeholders [53];

- Making the ES concept more 'actionable' $[13,33]$.

\subsection{Making Things Visible}

Making things visible is about making spatial representations to translate or reveal any kind of knowledge in a holistic way, by means of an artefact that can be perceived. It is about 1) mapping to reveal often invisible knowledge (e.g. sense of place, social processes), 2) translating or making abstract knowledge visible and understandable in spatially explicit representations (e.g. scenarios), and 3) framing of (normative) perspectives and values (e.g. to identify important issues, to create arguments). It can be about knowledge on the existing as well as on the possible and desired; it can have an analytical dimension as well as a normative dimension [162,163].

One of the fundamental characteristics of landscape design as imaginative research method, is the use of spatial representation as means of communication. A whole range of techniques and devices are being used for these purposes: 2D and 3D drawings, maps, models, computer games, etc. The use of representations can reveal different perspectives, create insights and understanding, identify topics, trigger the discussion and interaction-because then it all becomes concrete [148]. The visual nature of repre- 
sentations is described as having a powerful influence on people's thinking and perception of things, and thus can be a means to change ideas [164-168].

For the ES assignment, making things visible through a landscape design approach enables:

- The visualization of the complexity of human-nature relationships and associated meanings and values $[25,44]$;

- A common basis to discuss, by making existing or novel landscapes concrete $[67,111]$.

\subsection{Designing with Transformation and Imagining Future Landscapes}

Landscapes are dynamic systems in space and time, change continuously and new landscapes emerge with changing life-styles [149]. In an ever faster changing world, there is an increasing necessity to deal with dynamic processes, transformation and the uncertainty this entails for the future states of the environment and society.

Landscape design is used to deal with time and the inherent dynamic character of a landscape as evolving system $[169,170]$. Designing with dynamic processes and transformation is about the capacity to deal with the past and the future, hypothetical circumstances, possibilities and probabilities, through designing with time. To induce change and respond to long-term processes, societal transitions, vision development and strategy making, a process orientation takes central stage in a landscape design approach [152]. This orientation enables landscape designers to see and understand where things come from and where they are going to or can go to.

The knowledge of landscape history (or the landscape biography) helps to understand landscape patterns, properties of landscape units, their spatial arrangements, development and change over time [171]. A concept used within landscape approaches to capture the multiple layers of a landscape with (visible) traces of former change and landscape structures, is that of a 'palimpsest' [172].

But especially, to unlock 'what might be' and 'what we desire', landscape design has a unique quality as explorative research method. Imagining future landscapes is about projecting and 'imagineering' other modes of how to inhabit the planet [122], through narrating and visualizing spatially explicit representations. By showing possibilities and activating new realities or a desired future, the real and the virtual are both equally observable and can be discussed [111,173], opening up a space for a critical agenda [37].

Janssens and Geldof [174] define different modes of 'future' approaches. Scenarios explore a range of plausible possibilities ('what if'), based on predicted circumstances ('what will be'). Through the 'utopian' dimension of landscape design, 'what we desire' can be explored as well $[119,174]$.

For the ES assignment, integrating time depth and an orientation towards the future through a landscape design approach, allows to:
- Integrate temporal demand-supply dynamics and preferences [48,97,102];

- Create a 'free place' for participants to play with ideas for the future without commitment [14];

- Represent experiments and hypotheses for possible or desirable future landscapes $[27,36,83]$.

\subsection{Applying an Iterative and Collaborative Process}

There is a general understanding that collaboration is a key element in the governance for a sustainable environment [156]. An extensive body of literature suggests that transformations in social-ecological systems are more likely when key actors feel ownership of their future environment [175]. Several authors address the role and importance of a collaborative design process for landscape change, to improve the human-nature relationships and promote Earth's stewardship (see e.g. Felson et al. [176]; Karrasch et al. [165]; Kempenaar et al. [148]; Musacchio [158]; Opdam [177]).

A core characteristic of a landscape design process is an iterative exploration, in which new insights come up and are made along the way of a critical feedback loop [178]. Within this process, a collaborative approach involving a range of stakeholders, plays a fundamental role [179]. Both through the iterative exploration and the active participation of stakeholders, a landscape design process has the capacity to share knowledge, reflection and development of ideas, and to generate support and engagement towards change by letting stakeholders taking ownership over the ideas [152]. Important in the process, is the joint exploring of knowledge and multiple perspectives, the collective interpretation of problems, possibilities and what is desired. At the same time, building a shared knowledge basis turns the design process into a social learning process as well.

For the ES assignment, applying a deliberative and collaborative landscape design approach can accommodate:

- Involving (local) experts and stakeholders [10,65];

- To put peoples' values more central [52-54];

- Knowledge co-production through participatory methods with both scientists and local experts and stakeholders $[14,58,59]$.

\subsection{Knowledge Inquiry Through Design Practice}

There is a growing acceptance of practice as a research method [158,180,181]. To link scientific knowledge with landscape change and engagement, leading to more inquiry in science and place-specific design, landscape design can be a powerful approach.

One of the characteristics of the discipline of landscape design is the relationship with the professional design practice [182]. Through projects and case studies, the design practice offers locations or a focus in the real world to direct questions, generate data, test propositions, engage with individuals and communities, or to reflect on theories and methods [183]. In this way, landscape design (or better 'research through design') becomes a research method by 
actively employing the act of design(ing) for knowledge inquiry $[182,184]$. The key to come to knowledge that has relevance and validity beyond the specific context lies in the development of generalizable principles through reflective processes in accordance with certain criteria within a scientific context $[132,185,186]$. These principles or design guidelines explicitly make conceptual connections between the necessary simplifications of science and the infinite complexity of 'anecdotal' findings and specific knowledge of a project [111]. And so, the application of scientific knowledge to a local context shifts towards building knowledge based on local findings [187].

With a view to the ES assignment, through real world applications the design practice can:

- Contextualize the concept of ES, make it spatially explicit [14,63,93] and more meaningful [44];

- Include local knowledge [25,53].

\section{Discussion and Conclusion}

\subsection{Discussion}

In this paper, we propose a landscape design approach as a possible way forward for genuine landscape change in order to meet the societal demand for ES. A more comprehensive approach of which the ES concept is part, but not the sole guiding principle. This is in line with what Kenter [52] state that the ES concept should be made subsidiary, treated as one element amongst others in broader, pluralistic, integrated approaches, encompassing living from, in and with the environment (see also Jacobs et al. [56]; Norgaard [188]). In this way, a landscape design approach fits within the transition in science to move away from reductionism to integration and synthesis through hybrid modes of research [189] and to bridge the science-practice interface [184,190].

With a landscape design approach a lot of the challenges mentioned in ES literature can be addressed, such as incorporating multiple values, applying multiple methods, the contextualization of ES, capturing the 'messy' and 'wicked' complexity of reality, more spatial accuracy, stakeholder participation and inclusion of local knowledge, real world applications, and a multi scalar approach in space and time. This corresponds to what Balvanera et al. [191] found about the contributing factors to the overall success of a programme on ecosystem change and society, which include: explicitly addressing integrated social-ecological systems; a focus on transformation-oriented research; adaptation of studies to their local context; and engagement with stakeholders. Koschke et al. [192] conclude that practice-oriented methods and tools to assess the ability of landscapes as reference units to provide ES are so far sparsely available. An interesting example of such an approach is the integrated geosystem approach as proposed by Bastian et al. [89].

The importance of the landscape is that it provides a context in which social-ecological interactions can be recognized and articulated, and within which different values can be understood, visions can be shared, negotiated and choices can be made $[89,111]$. This is in line with the suggestion of Potschin and Haines-Young [63] to focus on 'place' and the integrating role that place-based thinking can play. It can also move the ES research out of the static mapping and evaluation approaches towards dynamic systems thinking and modelling [64].

A design approach enables to identify drivers of change, and to envision and co-construct strategies and actions that are likely to set the development towards the desired future situation into motion $[152,173]$. Something that can be addressed through research through design is the imaginative creation of other relationships between human and environment, where traditional science is more focused on understanding or the explanation of the relationship [174].

Within a landscape design approach the ES concept is well placed to:

- Understand and raise awareness why nature matters for humans;

- Assess certain aspects of ecosystems for human wellbeing;

- Address socio-ecological problems in the balance between potential, use and demand of ES.

The use of the ES concept to raise awareness is in line with the understanding of ES as ecological indicator [193], a communication tool that facilitates a simplification of the high complexity in human-environmental systems. As an assessment tool, within a landscape design approach the ES concept can be used by targeting certain ES without losing the awareness that the indicators address only a part of a larger whole [52]. Furthermore, the integration of the societal need for services and the distinction between potential, flow (de facto used ES, for example from remote regions) and demand for services can enhance the currently function-oriented landscape approaches [30,102].

\subsection{Conclusion: The Agency of Landscape Design to Meet the Societal Demand for Ecosystem Services}

The ES concept and the cascade-framework have generated a paradigm shift in the perspective of human society on nature and both had an important awareness-raising role concerning the importance of ecosystems. However, up to now the concept has not been capable to stop the loss of biodiversity and nature, especially in urbanized territories. As Norgaard ([188], p. 1220) puts it "[the] enthusiasm for optimizing the economy by including ES has blinded us to the more important question of how we are going to make the substantial institutional changes to significantly reduce human pressure on ecosystems".

To improve our living environment, design and planning are decisive steps. From the reviewed literature, however, it is obvious that the implementation of the ES concept within spatial design and planning processes poses several difficulties. In this context we state that in order to meet the societal challenges related to biodiversity loss and ES provision, another approach is needed that goes beyond theory and conceptualization, beyond problem solving and looking 
for possible solutions that fit within a certain political and social maneuvering space. A more comprehensive approach is needed, that better connects with the scale and complexity of the human living environment where landscape change occurs. An approach of which the ES concept is part.

To move from agendas, scientific knowledge, theories, concepts and models to genuine landscape change, we believe that a landscape design approach is indispensable. The integrative nature and the 'knowability' of the landscape, a deliberative and collaborative design approach, making things visible and imagining future landscapes are key aspects that characterise the powerful role or agency of design at the landscape scale. The notion of agency refers to an energy of action activated by design to 'make things

\section{References and Notes}

[1] Chee YE. An Ecological Perspective on the Valuation of Ecosystem Services. Biological Conservation. 2004;120:549-565. doi:10.1016/j.biocon.2004.03.028.

[2] Gómez-Baggethun E, de Groot R. Natural Capital and Ecosystem Services: The Ecological Foundation of Human Society. In: Ecosystem Services. vol. 30; 2010. pp. 105-121. doi:10.1039/9781849731058-00105.

[3] Costanza R, D'Arge R, de Groot R, Farber S, Grasso M, Hannon B, et al. The Value of the World's Ecosystem Services and Natural Capital. Nature. 1997;387:253-260. doi:10.1016/S09218009(98)00020-2.

[4] Millennium Ecosystem Assessment (MEA). Ecosystems and Human Well-being: Synthesis. Washington DC, USA: Island Press; 2005. Available from: https://www.millenniumassessment.org/documents/ document.356.aspx.pdf.

[5] Kumar P, editor. The Economics of Ecosystems and Biodiversity: Ecological and Economic Foundations. London and Washington, UK and USA: Earthscan; 2010.

[6] Global Assessment Report on Biodiversity and Ecosystem Services of the Intergovernmental Science- Policy Platform on Biodiversity and Ecosystem Services. Bonn, Germany: Intergovernmental Science- Policy Platform on Biodiversity and Ecosystem Services (IPBES); 2019.

[7] Díaz S, Demissew S, Carabias J, Joly C, Lonsdale M, Ash N, et al. The IPBES Conceptual Framework-connecting Nature and People. Current Opinion in Environmental Sustainability. 2015;14:1-16.

[8] Braat LC, de Groot R. The Ecosystem Services Agenda: Bridging the Worlds of Natural Science and Economics, Conservation and Development, and Public and Private Policy. Ecosystem Services. 2012;1:4-15. doi:10.1016/j.ecoser.2012.07.011.

[9] Costanza R, de Groot R, Braat L, Kubiszewski I, Fioramonti L, Sutton P, et al. Twenty Years of Ecosystem Services: How far Have We Come and How far do We still Need to Go? Ecosystem Services. 2017;28:1-16. doi:10.1016/j.ecoser.2017.09.008.

[10] Dick J, Turkelboom F, Woods H, Iniesta-Arandia I, Primmer E, Saarela SR, et al. Stakeholders' Perspectives on the Operationalisation of the Ecosystem Service Concept: Results from 27 Case Studies. Ecosystem Services. 2018;29:552-565. doi:10.1016/j.ecoser.2017.09.015.

[11] Maes J, Liquete C, Teller A, Erhard M, Paracchini ML, Barredo Jl, et al. An Indicator Framework for Assessing Ecosystem Services in Support of the EU Biodiversity Strategy to 2020. Ecosystem Services. 2016;17:14-23. doi:10.1016/j.ecoser.2015.10.023.

[12] Potschin M, Haines-Young R, Fish R, Turner RK, editors. Routledge Handbook of Ecosystem Services. Routledge; 2016.

[13] Ruckelshaus M, McKenzie E, Tallis H, Guerry A, Daily G, Kareiva P, et al. Notes from the Field: Lessons Learned from Using Ecosystem Service Approaches to Inform Real-World Decisions. Ecological happen' [194]. As an integrated, transformative, explorative and imaginative approach - a landscape design approach can play a significant role to activate genuine landscape change and a shift in land use and land stewardship to safeguard biodiversity and nature in order to provide a wide range of ES.

\section{Acknowledgements}

This paper is written as part of the Treescape research project (Treescape: From forest ecosystem services to spatial forest configurations for an urbanized territory), funded by the Research Foundation Flanders (FWO, G079418N).

Economics. 2015;115:11-21. doi:10.1016/j.ecolecon.2013.07.009. [14] Saarikoski H, Primmer E, Saarela SR, Antunes P, Aszalós R, Baró $\mathrm{F}$, et al. Institutional Challenges in Putting Ecosystem Service Knowledge in Practice. Ecosystem Services. 2018;29:579-598. doi:10.1016/j.ecoser.2017.07.019.

[15] Schröter M, Albert C, Marques A, Tobon W, Lavorel S, Maes J, et al. National Ecosystem Assessments in Europe: A Review. BioScience. 2016;66(10):813-828. doi:10.1093/biosci/biw101.

[16] Kieslich M, Salles JM. Implementation Context and Sciencepolicy Interfaces: Implications for the Economic Valuation of Ecosystem Services. Ecological Economics. 2021;179:106857. doi:10.1016/j.ecolecon.2020.106857.

[17] Croci E, Lucchitta B, Penati T. Valuing Ecosystem Services at the Urban Level: A Critical review. Sustainability (Switzerland). 2021;13(3):1-16. doi:10.3390/su13031129.

[18] Pauleit S, Ambrose-Oji B, Andersson E, Anton B, Buijs A, Haase D, et al. Advancing Urban Green Infrastructure in Europe: Outcomes and Reflections from the GREEN SURGE Project. Urban Forestry and Urban Greening. 2019;40:4-16. doi:10.1016/j.ufug.2018.10.006.

[19] Tzoulas K, Korpela K, Venn S, Yli-Pelkonen V, Kaźmierczak A, Niemela J, et al. Promoting ecosystem and human health in urban areas using Green Infrastructure: A literature review. Landscape and Urban Planning. 2007;81(3):167-178. doi:10.1016/j.landurbplan.2007.02.001.

[20] Maes J, Jacobs S. Nature-Based Solutions for Europe's Sustainable Development. Conservation Letters. 2017;10(1):121-124. doi:10.1111/conl.12216.

[21] Green infrastructure (GI)-enhancing Europe's Natural Capital. Brussels, Belgium: European Commission; 2013. Available from: http://eur-lex.europa.eu/legal-content/EN/TXT/?uri=CELEX: 52013DC0249.

[22] Policy Topics: Nature-based Solutions. Brussels, Belgium: European Commission; 2016. Available from: https://ec-europa-eu.kuleuven.ezproxy.kuleuven.be/research/ environment/index.cfm?Pg=nbs.

[23] Escobedo FJ, Giannico V, Jim CY, Sanesi G, Lafortezza R. Urban Forests, Ecosystem Services, Green Infrastructure and Nature-based Solutions: Nexus or Evolving Metaphors? Urban Forestry and Urban Greening. 2019;37:3-12. doi:10.1016/j.ufug.2018.02.011.

[24] Haines-Young R, Potschin M. The Links between Biodiversity, Ecosystem Services and Human Well-being. In: Frid CLJ, Raffaelli DG, editors. Ecosystem Ecology: A New Synthesis. Ecological Reviews. Cambridge University Press; 2010. pp. 110-139. doi:10.1017/CBO9780511750458.007.

[25] Potschin-Young M, Haines-Young R, Görg C, Heink U, Jax K, Schleyer C. Understanding the Role of Conceptual Frameworks: Reading the Ecosystem Service Cascade. Ecosystem Services. 2018;29:428-440. doi:10.1016/j.ecoser.2017.05.015. 
[26] Albert C, Aronson J, Fürst C, Opdam P. Integrating Ecosystem Services in Landscape Planning: Requirements, Approaches, and Impacts. Landscape Ecology. 2014;29:1277-1285. doi:10.1007/s10980-014-0085-0.

[27] Jax K, Furman E, Saarikoski H, Barton DN, Delbaere B, Dick J, et al. Handling a Messy World: Lessons Learned when Trying to Make the Ecosystem Services Concept Operational. Ecosystem Services. 2018;29:415-427. doi:10.1016/j.ecoser.2017.08.001.

[28] Gómez-Baggethun E, Barton DN. Classifying and Valuing Ecosystem Services for Urban Planning. Ecological Economics. 2013;86:235-245. doi:10.1016/j.ecolecon.2012.08.019.

[29] Bouma JA, van Beukering PJH. Ecosystem services: from concept to practice. In: Bouma JA, van Beukering PJH, editors. Ecosystem services: from concept to practice. Cambridge University Press; 2015. doi:10.1017/CBO9781107477612.

[30] de Groot RS, Alkemade R, Braat L, Hein L, Willemen L. Challenges in Integrating the Concept of Ecosystem Services and Values in Landscape Planning, Management and Decision Making. Ecological Complexity. 2010;7:260-272. doi:10.1016/j.ecocom.2009.10.006.

[31] Maes J, Egoh B, Willemen L, Liquete C, Vihervaara P, Schägner JP, et al. Mapping Ecosystem Services for Policy Support and Decision Making in the European Union. Ecosystem Services. 2012;1(1):3139. doi:10.1016/j.ecoser.2012.06.004.

[32] Cowell R, Lennon M. The Utilisation of Environmental Knowledge in Landuse Planning: Drawing Lessons for an Ecosystem Services Approach. Environment and Planning C: Government and Policy. 2014;32:263-282. doi:10.1068/c12289j.

[33] Dendoncker N, Turkelboom F, Boeraeve F, Boerema A, Broekx $\mathrm{S}$, Fontaine $\mathrm{C}$, et al. Integrating Ecosystem Services Values for Sustainability? Evidence from the Belgium Ecosystem Services Community of Practice. Ecosystem Services. 2018;31:68-76. doi:10.1016/j.ecoser.2018.03.006.

[34] Patenaude G, Lautenbach S, Paterson JS, Locatelli T, Dormann CF, Metzger MJ, et al. Breaking the Ecosystem Services Glass Ceiling: Realising Impact. Regional Environmental Change. 2019;pp. 1-14. doi:10.1007/s10113-018-1434-3.

[35] Russel D, Jordan A, Turnpenny J. The Use of Ecosystem Services Knowledge in Policy-making: Drawing Lessons and Adjusting Expectations. In: Potschin M, Haines-Young R, Fish R, Turner RK, editors. Routledge Handbook of Ecosystem Services. Routledge; 2016. pp. 586-596. doi: $10.4324 / 9781315775302$.

[36] Costanza R, Kubiszewski I. A Nexus Approach to Urban and Regional Planning Using the Four-Capital Framework of Ecological Economics. In: Hettiarachchi H, Ardakanian R, editors. Environmental Resource Management and the Nexus Approach: Managing Water, Soil, and Waste in the Context of Global Change. Springer International Publishing; 2016. pp. 79-111. doi:10.1007/978-3-31928593-1.

[37] Fry T. Design for/by “The Global South”. Design Philosophy Papers. 2017;15(1):3-37.

[38] Galler C, Albert C, von Haaren C. From Regional Environmental Planning to Implementation: Paths and Challenges of Integrating Ecosystem Services. Ecosystem Services. 2016;18:118-129. doi:10.1016/j.ecoser.2016.02.031.

[39] Daily GC, editor. Nature's Services: Societal Dependence on Natural Ecosystems. Island Press; 1997.

[40] de Groot RS. Environmental Functions and the Economic Value of Natural Ecosystems. In: Jansson M, Hammer M, Folke C, Costanza R, editors. Investing in Natural Capital: The Ecological Economics Approach to Sustainability. Island Press, International Society for Ecological Economics; 1994. pp. 151-168.

[41] Kull CA, Arnauld de Sartre X, Castro-Larrañaga M. The Political Ecology of Ecosystem Services. Geoforum. 2015;61:122-134. doi:10.1016/j.geoforum.2015.03.004.

[42] Braat LC. Five Reasons Why the Science Publication "Assessing Nature's contributions to people" (Diaz et al. 2018) Would not Have Been Accepted in Ecosystem Services. Ecosystem Services. 2018;30:A1-A2. doi:10.1016/j.ecoser.2018.02.002.

[43] Maes J, Burkhard B, Geneletti D. Ecosystem Services are Inclusive and Deliver Multiple Values. A comment on the Concept of Nature's Contributions to People, volume $=3$, year $=2018$. One Ecosystem;pp. 1-5. doi:10.3897/oneeco.3.e24720.
[44] Termorshuizen JW, Opdam P. Landscape Services as a Bridge between Landscape Ecology and Sustainable Development. Landscape Ecology. 2009;24:1037-1052. doi:10.1007/s10980-008-93148

[45] Gómez-Baggethun E, Martín-López B. Ecological Economics Perspectives on Ecosystem Services Valuation. In Martínez-Alier J, Muradian R, editors. Handbook of Ecological Economics. Edward Elgar Publishing; 2015. pp. 260-282. doi:10.4337/9781783471416.00015.

[46] Pascual U, Balvanera P, Díaz S, Pataki G, Roth E, Stenseke M, et al. Valuing Nature's Contributions to People: the IPBES Approach. Current Opinion in Environmental Sustainability. 2017;26-27:7-16. doi:10.1016/j.cosust.2016.12.006.

[47] Liu J, Opdam P. Valuing Ecosystem Services in Community-based Landscape Planning: Introducing a Wellbeing-based Approach. Landscape Ecology. 2014;29:1347-1360. doi:10.1007/s10980-0140045-8.

[48] Hermann A, Schleifer S, Wrbka T. The Concept of Ecosystem Services Regarding Landscape Research: A Review. Living Reviews in Landscape Research. 2011;5:1-37. doi:10.12942/rlr-2011-1.

[49] Martín-López B, Gómez-Baggethun E, García-Llorente M, Montes C. Trade-offs across Value-domains in Ecosystem Services Assessment. Ecological Indicators. 2014;37:220-228. doi:10.1016/j.ecolind.2013.03.003.

[50] James SP. Cultural Ecosystem Services: A Critical Assessment. Ethics, Policy and Environment. 2015;18(3):338-350. doi:10.1080/21550085.2015.1111616.

[51] Ives CD, Kendal D. Values and Attitudes of the Urban Public towards Peri-urban Agricultural Land. Land Use Policy;pp. 80-90. doi:10.1016/j.landusepol.2013.02.003.

[52] Kenter JO. IPBES: Don't throw out the Baby Whilst Keeping the Bathwater; Put People's Values Central, not $\mathrm{Na}$ ture's Contributions. Ecosystem Services. 2018;33:40-43. doi:10.1016/j.ecoser.2018.08.002.

[53] Turkelboom F, Leone M, Jacobs S, Kelemen E, García-Llorente M, Baró $F$, et al. When We Cannot have it all: Ecosystem Services Trade-offs in the Context of Spatial Planning. Ecosystem Services. 2018;29:566-578. doi:10.1016/j.ecoser.2017.10.011.

[54] Díaz S, Pascual U, Stenseke M, Martín-López B, Watson RT, Molnár Z, et al. Assessing Nature's Contributions to People: Recognizing Culture, and Diverse Sources of Knowledge, Can Improve Assessments. Science. 2018;359(6373):270-272. doi:10.1126/science.aap8826.

[55] Dunford R, Harrison P, Smith A, Dick J, Barton DN, Martin-Lopez B, et al. Integrating Methods for Ecosystem Service Assessment: Experiences from Real World Situations. Ecosystem Services. 2018;29:499-514. doi:10.1016/j.ecoser.2017.10.014.

[56] Jacobs S, Dendoncker N, Martín-López B, Barton DN, GomezBaggethun E, Boeraeve $F$, et al. A New Valuation School: Integrating Diverse Values of Nature in Resource and Land Use Decisions. Ecosystem Services. 2016;22:213-220. doi:10.1016/j.ecoser.2016.11.007.

[57] Carmen E, Watt A, Carvalho L, Dick J, Fazey I, Garcia-Blanco G et al. Knowledge Needs for the Operationalisation of the Concept of Ecosystem Services. Ecosystem Services. 2018;29:441-451. doi:10.1016/j.ecoser.2017.10.012.

[58] Kenter JO, Brien L, Hockley N, Ravenscroft N, Fazey I, Irvine $\mathrm{KN}$, et al. What are Shared and Social Values of Ecosystems? Ecological Economics. 2015;111:86-99. doi:10.1016/..ecolecon.2015.01.006.

[59] Milcu A, Hanspach J, Abson D, Fischer J. Cultural Ecosystem Services: A Literature Review and Prospects for Future Research. Ecology and Society. 2013;18(3):44. doi:10.5751/ES-05790-180344.

[60] Schägner JP, Brander L, Maes J, Hartje V. Mapping Ecosystem Services' Values: Current Practice and Future Prospects. Ecosystem Services. 2013;4:33-46. doi:10.1016/j.ecoser.2013.02.003.

[61] Seppelt R, Dormann C, Eppink F, Lautenbach S, Schmidt S. A Quantitative Review of Ecosystem Service Studies: Approaches, Shortcomings and the Road Ahead. The Journal of Applied Ecology;(3):630-636. doi:10.1111/j.1365-2664.2010.01952.x.

[62] Martínez-Harms MJ, Balvanera P. Methods for Mapping Ecosystem Service Supply: A Review. International Journal of Biodiversity Sci- 
ence, Ecosystem Services and Management. 2012;8(1-2):17-25. doi:10.1080/21513732.2012.663792.

[63] Potschin M, Haines-Young R. Landscapes, Sustainability and the Place-based Analysis of Ecosystem Services. Landscape Ecology. 2013;28:1053-1065. doi:10.1007/s10980-012-9756-x.

[64] Opdam P. Using Ecosystem Services in Community- Based Landscape Planning: Science is Not Ready to Deliver. In: Fu B, Jones KB, editors. Landscape Ecology for Sustainable Environment and Culture. Dordrecht, Netherlands: Springer; 2013. pp. 77-101. doi:10.1007/978-94-007-6530-6_5.

[65] Spangenberg JH, Görg C, Settele J. Stakeholder Involvement in ESS Research and Governance: Between Conceptual Ambition and Practical Experiences - Risks, Challenges and Tested Tools. Ecosystem Services. 2015;16:201-211. doi:10.1016/j.ecoser.2015.10.006.

[66] Ruiz-Frau A, Edwards-Jones G, Kaiser MJ. Mapping Stakeholder Values for Coastal Zone Management. Marine Ecology Progress Series. 2011;434:239-249. doi:10.3354/meps09136.

[67] Pocock MJO, Evans DM, Fontaine C, Harvey M, Julliard R, McLaughlin Ó, et al. The Visualisation of Ecological Networks, and Their Use as a Tool for Engagement, Advocacy and Management. In: Advances in Ecological Research. vol. 54. Academic Press; 2016. pp. 41-85. doi:10.1016/bs.aecr.2015.10.006.

[68] Andersson E, Tengö M, McPhearson T, Kremer P. Cultural Ecosystem Services as a Gateway for Improving Urban Sustainability. Ecosystem Services. 2015;12:165-168. doi:10.1016/j.ecoser.2014.08.002.

[69] Costanza R, Alperovitz G, Daly H, Farley J, Franco C, Jackson $\mathrm{T}$, et al. Building a Sustainable and Desirable Economyin-Society-in-Nature. In: Shmelev S, editor. Green Economy Reader. vol. 6. Springer International Publishing; 2017. pp. 367-454. doi:10.1007/978-3-319-38919-6.

[70] Raymond CM, Giusti M, Barthel S. An Embodied Perspective on the Co-production of Cultural Ecosystem Services: Toward Embodied Ecosystems. Journal of Environmental Planning and Management. 2018;61(5-6):778-799. doi:10.1080/09640568.2017.1312300.

[71] Alberti M. The Effects of Urban Patterns on Ecosystem Function. 2005;28(2):168-192. doi:10.1177/0160017605275160.

[72] Wu J, Buyantuyev A, Jenerette GD, Litteral J, Neil K, Shen W. Quantifying Spatiotemporal Patterns and Ecological Effects of Urbanization: A Multiscale Landscape Approach. Applied Urban Ecology: A Global Framework. 2011;pp. 33-53.

[73] Haase D. How is Urban Land Use Unique. In: Seto KC, Reenberg A, editors. Rethinking Global Land Use in an Urban Era. vol. 14. MIT Press; 2014. pp. 299-311.

[74] Dewaelheyns V, Leinfelder H, Gulinck $\mathrm{H}$. Challenging the Boxes. Interfaces in Landscape and Land use. Dewaelheyns V, Leinfelder H, Gulinck H, editors. Gompel\&Svacina; 2018.

[75] Reyers B, Biggs R, Cumming GS, Elmqvist T, Hejnowicz AP, Polasky S. Getting the Measure of Ecosystem Services: A Socialecological Approach. Frontiers in Ecology and the Environment. 2013;11(5):268-273. doi:10.1890/120144.

[76] Barot S, Yé L, Abbadie L, Blouin M, Frascaria N. Ecosystem Services must Tackle Anthropized Ecosystems and Ecological Engineering. Ecological Engineering. 2017;99:486-495. doi:10.1016/j.ecoleng.2016.11.071.

[77] Heink U, Hauck J, Jax K, Sukopp U. Requirements for the Selection of Ecosystem Service Indicators-The case of MAES Indicators. Ecological indicators. 2016;61:18-26.

[78] Hauck J, Görg C, Varjopuro R, Ratamäki O, Maes J, Wittmer $\mathrm{H}$, et al. "Maps Have an Air of Authority": Potential Benefits and Challenges of Ecosystem Service Maps at Different Levels of Decision Making. Ecosystem Services. 2013;4:25-32. doi:10.1016/j.ecoser.2012.11.003.

[79] Tasser E, Schirpke U, Zoderer BM, Tappeiner U. Towards an Integrative Assessment of Land-use Type Values from the Perspective of Ecosystem Services. Ecosystem Services. 2020;42:101082. doi:10.1016/j.ecoser.2020.101082.

[80] Chan KMA, Balvanera P, Benessaiah K, Chapman M, Díaz S, Gómez-Baggethun E, et al. Opinion: Why Protect Nature? Rethinking Values and the Environment. Proceedings of the National Academy of Sciences. 2016;113(6):1462-1465. doi:10.1073/pnas.1525002113.

[81] Davidson MD. On the Relation between Ecosystem Services, Intrinsic Value, Existence Value and Economic Valuation. Ecological Economics. 2013;95:171-177. doi:10.1016/j.ecolecon.2013.09.002.

[82] Grimaldi M, Oszwald J, Dolédec S, del Pilar Hurtado M, de Souza Miranda I, De Sartre XA, et al. Ecosystem Services of Regulation and Support in Amazonian Pioneer Fronts: Searching for Landscape Drivers. Landscape ecology. 2014;29(2):311-328.

[83] Small N, Munday M, Durance I. The Challenge of Valuing Ecosystem Services that Have no Material Benefits. Global Environmental Change. 2017;44:57-67. doi:10.1016/j.gloenvcha.2017.03.005.

[84] Scholte SSK, van Teeffelen AJA, Verburg PH. Integrating Sociocultural Perspectives into Ecosystem Service Valuation: A Review of Concepts and Methods. Ecological Economics. 2015;114:67-78. doi:10.1016/j.ecolecon.2015.03.007.

[85] Rusch VE, Rusch GM, Goijman AP, Varela SA, Claps L. Ecosystem Services to Support Environmental and Socially Sustainable Decision-making; 2017. Available from: http://hdl.handle.net/11250/ 2447318.

[86] Spake R, Lasseur R, Crouzat E, Bullock JM, Lavorel S, Parks $\mathrm{KE}$, et al. Unpacking Ecosystem Service Bundles: Towards Predictive Mapping of Synergies and Trade-offs between Ecosystem Services. Global Environmental Change. 2017;47:37-50. doi:10.1016/j.gloenvcha.2017.08.004.

[87] Bennett EM, Peterson GD, Gordon LJ. Understanding Relationships among Multiple Ecosystem Services. Ecology letters. 2009;12(12):1394-1404. doi:10.1111/j.1461-0248.2009.01387.x.

[88] Bennett EM, Cramer W, Begossi A, Cundill G, Díaz S, Egoh BN et al. Linking Biodiversity, Ecosystem Services, and Human Wellbeing: Three Challenges for Designing Research for Sustainability. Current Opinion in Environmental Sustainability. 2015;14:76-85. doi:10.1016/j.cosust.2015.03.007.

[89] Bastian O, Grunewald K, Khoroshev AV. The Significance of Geosystem and Landscape Concepts for the Assessment of Ecosystem Services: Exemplified in a Case Study in Russia. Landscape Ecology. 2015;30(7):1145-1164. doi:10.1007/s10980-015-0200-x.

[90] Muñoz-Rojas J, Angelstam P, Elbakidze M, Díaz-Maroto I. IALE 2017-From pattern and process to people and action; 2017.

[91] Grote R, Samson R, Alonso R, Amorim JH, Cariñanos P, Churkina G, et al. Functional Traits of Urban Trees: Air Pollution Mitigation Potential. Frontiers in Ecology and the Environment. 2016;14(10):543550. doi:10.1002/fee.1426.

[92] Nicholson E, Mace GM, Armsworth PR, Atkinson G, Buckle S, Clements T, et al. Priority Research Areas for Ecosystem Services in a Changing World. Journal of Applied Ecology. 2009;46(6):11391144. doi:10.1111/j.1365-2664.2009.01716.x.

[93] Renard D, Rhemtulla JM, Bennett EM. Historical Dynamics in Ecosystem Service Bundles. Proceedings of the National Academy of Sciences. 2015;112(43):13411-13416. doi:10.1073/pnas. 1502565112

[94] Spatial Scales, Stakeholders and the Valuation of Ecosystem Services. Ecological Economics. 2006;57:209-228. doi:10.1016/j.ecolecon.2005.04.005.

[95] Dallimer M, Davies ZG, Diaz-Porras DF, Irvine KN, Maltby L, Warren $\mathrm{PH}$, et al. Historical Influences on the Current Provision of Multiple Ecosystem Services. Global Environmental Change. 2015;31:307317. doi:10.1016/j.gloenvcha.2015.01.015.

[96] Tomscha SA, Gergel SE. Ecosystem Service Trade-offs and Synergies Misunderstood without Landscape History. Ecology and Society. 2016;21(1). doi:10.5751/ES-08345-210143.

[97] Bürgi M, Silbernagel J, Wu J, Kienast F. Linking Ecosystem Services with Landscape History. Landscape Ecology. 2015;30:11-20. doi:10.1007/s10980-014-0102-3.

[98] Eigenbrod F, Armsworth PR, Anderson BJ, Heinemeyer A, Gillings S, Roy DB, et al. The Impact of Proxy-based Methods on Mapping the Distribution of Ecosystem Services. Journal of Applied Ecology 2010;47:377-385. doi:10.1111/j.1365-2664.2010.01777.x.

[99] Ottoy S, Vanierschot L, Dondeyne S, Vancampenhout K, Hermy M, Van Orshoven J. The Devil is in the Detail: Discrepancy between Soil Organic Carbon Stocks Estimated from Regional and Local Data Sources in Flanders, Belgium. Soil Use and Management. 2019;pp. 1-12. doi:10.1111/sum.12504. 
[100] Mulder C, Bennett EM, Bohan DA, Bonkowski M, Carpenter SR, Chalmers R, et al. In: Advances in Ecological Research. vol. 53; 2015. pp. 1-53. doi:10.1016/bs.aecr.2015.10.005

[101] Berkes F. From Community-Based Resource Management to Complex Systems: The Scale Issue and Marine Commons. Ecology and Society. 2006;11(1). doi:10.5751/ES-01431-110145.

[102] Burkhard B, Kandziora M, Hou Y, Müller F. Ecosystem Service Potentials, Flows and Demands-concepts for Spatial Localisation, Indication and Quantification. Landscape Online. 2014;34:1-32. doi:10.3097/LO.201434.

[103] García-Nieto AP, García-Llorente M, Iniesta-Arandia I, MartínLópez B. Mapping Forest Ecosystem Services: From Providing Units to Beneficiaries. Ecosystem Services. 2013;4:126-138. doi:10.1016/j.ecoser.2013.03.003.

[104] Syrbe RU, Walz U. Spatial Indicators for the Assessment of Ecosystem Services: Providing, Benefiting and Connecting Areas and Landscape Metrics. Ecological Indicators. 2012;21:80-88. doi:10.1016/j.ecolind.2012.02.013.

[105] Andersson E, McPhearson T, Kremer P, Gomez-Baggethun E, Haase D, Tuvendal M, et al. Scale and Context Dependence of Ecosystem Service Providing Units. Ecosystem Services. 2015;12:157-164. doi:10.1016/j.ecoser.2014.08.001.

[106] Opdam P, Nassauer JI, Wang Z, Albert C, Bentrup G, Castella JC, et al. Science for Action at the Local Landscape Scale. Landscape Ecology. 2013;28:1439-1445. doi:10.1007/s10980-013-9925-6.

[107] Swaffield S. Empowering Landscape Ecology-connecting Science to Governance through Design Values. Landscape Ecology. 2013;28:1193-1201. doi:10.1007/s10980-012-9765-9.

[108] Griggs D, Stafford-Smith M, Gaffney O, Rockström J, Öhman MC, Shyamsundar P, et al. Sustainable Development Goals for People and Planet. Nature. 2013;495(7441):305-307. doi:10.1038/495305a.

[109] Berkes F, Folke C. Linking Social and Ecological Systems: Management Practices and Social Mechanisms for Building Resilience. Cambridge: Cambridge University Press; 1998.

[110] Bastian O, Grunewald K, Syrbe RU, Walz U, Wende W. Landscape Services: The Concept and its Practical Relevance. Landscape Ecology. 2014;29:1463-1479. doi:10.1007/s10980-014-0064-5.

[111] Nassauer Jl. Landscape as Medium and Method for Synthesis in Urban Ecological Design. Landscape and Urban Planning. 2012;106:221-229. doi:10.1016/j.landurbplan.2012.03.014.

[112] Antrop M, Van Eetvelde V. Landscape Perspectives: The Holistic Nature of Landscape. vol. 23. Springer; 2017. doi:10.1007/978-94024-1183-6.

[113] Naveh Z. Ten Major Premises for a Holistic Conception of Multifunctional Landscapes. Landscape and Urban Planning. 2001;57:269284. doi:10.1016/S0169-2046(01)00209-2.

[114] Pedroli B, Antrop M, Pinto Correia T. Editorial: Living Landscape: The European Landscape Convention in Research Perspective. Landscape Research. 2013;38(6):691-694. doi:10.1080/01426397.2013.873269.

[115] Zonneveld IS. Land Ecology: An Introduction to Landscape Ecology as a Base for Land Evaluation, Land Management and Conservation. SPB Academic Publishing; 1995.

[116] of Europe C. European Landscape Convention. Council of Europe; 2000.

[117] Antrop M. Sustainable Landscapes: Contradiction, Fiction or Utopia? Landscape and Urban Planning. 2006;75:187-197. doi:10.1016/j.landurbplan.2005.02.014.

[118] Selman P. Planning at the Landscape Scale. Routledge; 2006.

[119] Potschin MB, Klug H, Haines-Young $\mathrm{RH}$. From Vision to Action: Framing the Leitbild Concept in the Context of Landscape Planning. Futures. 2010;42:656-667. doi:10.1016/j.futures.2010.04.003.

[120] World Urbanization Prospects 2018. United Nations, Department of Economic and Social Affairs; 2018.

[121] Rockström J, Steffen W, Noone K, Persson Å, Chapin III FS, Lambin EF, et al. A Safe Operating Space for Humanity. Nature. 2009;461:472-475. doi:10.1016/j.jen.2014.01.005.

[122] Janssens N. Utopia-driven Projective Research. Gothenburg, Sweden; 2012. Available from: https://core.ac.uk/download/pdf/ 34595366.pdf.

[123] Glanville R. The Sometimes Uncomfortable Marriages of Design and Research. In: Rodgers P, Yee J, editors. The Routledge Companion to Design Research. Routledge; 2015. pp. 9-22.

[124] Lenzholzer S, Duchhart I, Koh J. 'Research through Designing' in Landscape Architecture. Landscape and Urban Planning 2013;113:120-127. doi:10.1016/j.landurbplan.2013.02.003.

[125] Doucet I, Janssens N. Editorial: Transdisciplinarity, the Hybridis ation of Knowledge Production and Space-Related Research. In Doucet I, Janssens N, editors. Transdisciplinary Knowledge Production in Architecture and Urbanism. Springer Science \& Business Media; 2011. pp. 1-14. doi:10.1007/978-94-007-0104-5

[126] Cross N. Designerly Ways of Knowing. Design Studies. 1982;3:221227. doi:10.1016/0142-694X(82)90040-0.

[127] Gibbons M, Limoges C, Nowotny H, Schwartzman S, Scott P, Trow M. New Production of Knowledge. Sage; 1994 doi:10.2307/2076669.

[128] Dunin-Woyseth H, Nilsson F. Transdisciplinarity, the Hybridisation of Knowledge Production and Space-Related Research. In: Doucet I, Janssens N, editors. Transdisciplinary Knowledge Production in Architecture and Urbanism. Springer Science \& Business Media 2011. pp. 79-96. doi:10.1007/978-94-007-0104-5.

[129] Steinitz C. A Framework for Geodesign: Changing Geography by Design. Esri Press; 2012

[130] Rodgers PA, Yee J. The Routledge Companion to Design Research. Routledge; 2015

[131] Groat LN, Wang D. Architectural Research Methods. John Wiley \& Sons; 2013.

[132] Stremke S, Schöbel S. Research through Design for Energy Transition: Two Case studies in Germany and The Netherlands. Smart and Sustainable Built Environment. 2019;8(1):16-33. doi:10.1108/SASBE-02-2018-0010.

[133] van De Weijer M, Van Cleempoel K, Heynen H. Positioning Research and Design in Academia and Practice: A Contribution to a Continuing Debate. Design Issues. 2014;30(2):17-29. doi:10.1162/DESI_a_00259.

[134] van den Brink A, Bruns D, Tobi H, Bell S, editors. Research in Landscape Architecture: Methods and Methodology. Routledge; 2017.

[135] Creswell JW. Research Design: Qualitative, Quantitative, and Mixed Methods Approaches. 2nd ed. Sage; 2003.

[136] Deming ME, Swaffield S. Landscape Architectural Research: Inquiry, Strategy, Design. John Wiley \& Sons; 2011.

[137] Frayling C. Research in Art and Design. Royal College of Art Research Papers. 1993;1(1):1-5. Available from: https://researchonline.rca.ac.uk/384/3/frayling_research_in_ art_and_design_1993.pdf.

[138] Jonas W. The Strengths/Limits of Systems Thinking denote the Strengths/Limits of Practice-Based Design Research. FormAkademisk-forskningstidsskrift for design og designdidaktikk 2014;7(4):1-11. doi:10.7577/formakademisk.789.

[139] Nijhuis S, Bobbink I. Design-related Research in Landscape Architecture. Journal of Design Research. 2012;10(4):239-257. doi:10.1504/jdr.2012.051172.

[140] Chow R. What should be Done with the Different Versions of Research Through Design. Entwerfen Wissen Produzieren Designforschung im Anwendungskontext. 2010;pp. 145-158.

[141] Volonté P, Rampino L, Colombo S. The Specificity of Design Research: How Practice-Based Design Knowledge Can Enter the Great Archive of Science. In: Vermaas PE, Vial S, editors. Advancements in the Philosophy of Design. Springer International Publishing; 2018. pp. 319-345.

[142] Howard P, Thompson I, Waterton E, editors. The Routledge Companion to Landscape Studies. Routledge; 2012.

[143] Swanwick C. Society's Attitudes to and Preferences for Land and Landscape. Land Use Policy. 2009;26:62-75. doi:10.1016/j.landusepol.2009.08.025.

[144] Opdam P, Westerink J, Vos C, de Vries B. The Role and Evolution of Boundary Concepts in Transdisciplinary Landscape Planning. Planning Theory and Practice. 2015;16(1):63-78 doi:10.1080/14649357.2014.997786.

[145] Arts B, Buizer M, Horlings L, Ingram V, Van Oosten C, Opdam P. Landscape Approaches: A State-of-the-Art Review. Annual Review of Environment and Resources. 2017;42:439-463. 
doi:10.1146/annurev-environ- 102016-060932 Copyright.

[146] Tress B, Tress G, van der Valk A, Fry G, editors. Interdisciplinary and Transdisciplinary Landscape Studies: Potential and Limitations. Delta Program; 2003.

[147] von Seggern H, Werner J. Designing as an Integrative Process of Creating Knowledge. In: von Seggern H, Werner J, Grosse-Bächle $\mathrm{L}$, editors. Creating Knowledge: Innovation Strategies for Designing Urban Landscapes. JOVIS Verlag; 2008. pp. 35-65.

[148] Kempenaar A, Westerink J, van Lierop $M$, Brinkhuijsen $M$, van den Brink A. "Design Makes you Understand"- Mapping the Contributions of Designing to Regional Planning and Development. Landscape and Urban Planning. 2016;149:20-30. doi:10.1016/j.landurbplan.2016.01.002.

[149] Antrop M. Continuity and Change in Landscapes. Landscape Change and the Urbanization Process in Europe. In: Mander U, Antrop M, editors. Multifunctional Landscapes - Volume 3: Continuity and Change. WIT Press; 2003. pp. 1-14.

[150] Plieninger T, Bieling C, editors. Resilience and the Cultural Landscape: Understanding and Managing Change in Human-shaped Environments. Cambridge University Press; 2012

[151] Barnett R. Emergence in Landscape Architecture. Routledge; 2013.

[152] Kempenaar A, van den Brink A. Regional Designing: A Strategic Design Approach in Landscape Architecture. Design Studies. 2018;54:80-95. doi:10.1016/j.destud.2017.10.006.

[153] Barton J, Haslett T. Analysis, Synthesis, Systems Thinking and the Scientific Method: Rediscovering the Importance of Open Systems. Systems Research and Behavioral Science: The Official Journal of the International Federation for Systems Research. 2007;24(2):143155.

[154] van Schaick J, Klaasen I. The Dutch Layers Approach to Spatial Planning and Design: A Fruitful Planning Tool or a Temporary Phenomenon? European Planning Studies. 2011;19(10):1775-1796.

[155] Dorst K. Frame Creation and Design in the Expanded Field. She Ji: The Journal of Design, Economics, and Innovation. 2015;1(1):2233. doi:10.1016/j.sheji.2015.07.003.

[156] Transforming Our World: The 2030 Agenda for Sustainable Development. New York, USA: United Nations, Department of Economic and Social Affairs; 2015

[157] Selman P. Sustainable Landscape Planning: The Reconnection Agenda. Routledge; 2012

[158] The Scientific Basis for the Design of Landscape Sustainability: A Conceptual Framework for Translational Landscape Research and Practice of Designed Landscapes and the Six Es of Landscape Sustainability. Landscape Ecology. 2009;24:993-1013. doi:10.1007/s10980-009-9396-y.

[159] Swaffield S. Landscape as a Way of Knowing the World. In: Harvey S, Fieldhouse K, editors. The Cultured Landscape: Designing the Environment in the $21^{\text {st }}$ Century. Routledge; 2005. pp. 3-23. doi:10.4324/9780203642252.

[160] Gobster PH, Nassauer JI, Daniel TC, Fry G. The Shared Landscape: What does Aesthetics Have to Do with Ecology? Landscape ecology. 2007;22(7):959-972.

[161] Luck GW, Daily GC, Ehrlich PR. Population Diversity and Ecosystem Services. Trends in Ecology \& Evolution. 2003;18(7):331-336.

[162] Balz VE, Zonneveld WAM. Regional Design in the Context of Fragmented Territorial Governance: South Wing Studio. European Planning Studies. 2015;23(5):871-891. doi:10.1080/09654313.2014.889662.

[163] Beelen K. The 'Region' as a Project of Cartographic Reconfiguration. In: Meijsmans N, Beelen K, editors. Designing for a Region. SUN Academia; 2010.

[164] Dulic A, Angel J, Sheppard S. Designing Futures: Inquiry in Climate Change Communication. Futures. 2016;81:54-67. doi:10.1016/j.futures.2016.01.004

[165] Karrasch L, Maier M, Klenke T, Kleyer M. Collaborative Landscape Planning: Co-design of Ecosystem-based Land Management Scenarios. Sustainability. 2017;9:1668. doi:10.3390/su9091668.

[166] Meijsmans N, Beelen K, editors. Designing for a Region. SUN Academia; 2010.

[167] Neuman M. The Imaginative Institution: Planning and Governance in Madrid; 2010.

[168] Sheppard SRJ. Making Climate Change Visible: A Critical Role for Landscape Professionals. Landscape and Urban Planning 2015;142:95-105. doi:10.1016/j.landurbplan.2015.07.006.

[169] Bowring J, Swaffield S. Shifting Landscapes In-Between Times. Harvard Design Magazine. 2011;36:96-104. Available from: http://www.harvarddesignmagazine.org/issues/36/shiftinglandscapes-in-between-times.

[170] Prominski M. Designing Landscapes as Evolutionary Systems. The Design Journal. 2005;8(3):25-34 doi:10.2752/146069205789331565

[171] Kolen J, Renes J. Landscape Biographies: Key Issues. In: Renes J, Hermans R, Kolen J, editors. Landscape Biographies: Geographical, Historical and Archaeological Perspectives on the Production and Transmission of Landscapes. Amsterdam University Press; 2015. pp. 21-47.

[172] Corboz A. The Land as Palimpsest. Diogenes. 1983;31(121):12-34. doi:10.1177/039219218303112102.

[173] Heynen H, Janssens N. Utopia-driven Projective Research. Boundaries. 2013;8:60-65.

[174] Janssens N, Geldof C. Implementing Design Characteristics of Utopian Thinking in Mechanisms of Worlding. In: Frichot $\mathrm{H}$, Sandin G, Schwalm B, editors. After Effects: Theories and Methodologies in Architectural Research. ACTAR Publishers; 2018.

[175] Armitage DR, Plummer R, Berkes F, Arthur RI, Charles AT, Davidson-Hunt IJ, et al. Adaptive Co-management for Social-Ecological Complexity. Frontiers in Ecology and the Environment. 2009;7(2):95-102. doi:10.1890/070089.

[176] Felson AJ, Bradford MA, Terway TM. Promoting Earth Stewardship through Urban Design Experiments. Frontiers in Ecology and the Environment. 2013;11(7):362-367. doi:10.1890/130061.

[177] Opdam P. Exploring the Role of sScience in Sustainable Landscape Management. An Introduction to the Special Issue. Sustainability 2018;10(2):331. doi:10.3390/su10020331.

[178] Barnett R. Exploration and Discovery: A Nonlinear Approach to Research by Design. Landscape Review. 2000;6(2):25-40.

[179] Meijering JV, Tobi H, van den Brink A, Morris F, Bruns D. Exploring Research Priorities in Landscape Architecture: An International Delphi Study. Landscape and Urban Planning. 2015;137:85-94. doi:10.1016/j.landurbplan.2015.01.002.

[180] Borgdorff HAH. The Conflict of the Faculties: Perspectives on Artistic Research and Academia. University Press; 2012.

[181] Sullivan G, editor. Art Practice as Research: Inquiry in Visual Arts Sage; 2010.

[182] Lenzholzer S, Cortesão J. Design Research Society 2018: Catalyst; 2018. 10.21606/drs.2018.293.

[183] Mottram J, Rust C. The Pedestal and the Pendulum: Fine Art Practice, Research and Doctorates. Journal of Visual Art Practice. 2008;7(2):133-151. doi:10.1386/jvap.7.2.133_1.

[184] Nassauer JI, Opdam P. Design in Science: Extending the Landscape Ecology Paradigm. Landscape Ecology. 2008;23:633-644. doi:10.1007/s10980-008-9226-7.

[185] Prominski M. Design Guidelines. In: van den Brink A, Bruns D, Tobi $\mathrm{H}$, Bell S, editors. Research in Landscape Architecture: Methods and Methodology. Routledge; 2017. pp. 194.

[186] Tress B, Tress G, Fry G. Defining Concepts and Process of Knowledge Production in Integrative Research. In: Tress B, Tres G, Fry G, Opdam P, editors. From Landscape Research to Landscape Planning: Aspects of Integration, Education and Application. Springer Science \& Business Media; 2005. pp. 13-26. doi:10.1007/978-1 4020-5363-4_2.

[187] Raymond CM, Fazey I, Reed MS, Stringer LC, Robinson GM Evely AC. Integrating Local and Scientific Knowledge for Environmental Management. Journal of Environmental Management. 2010;91(8):1766-1777. doi:10.1016/j.jenvman.2010.03.023.

[188] Norgaard RB. Ecosystem Services: From Eye-opening Metaphor to Complexity Blinder. Ecological Economics. 2010;69:1219-1227. doi:10.1016/j.ecolecon.2009.11.009.

[189] Sayer J, Campbell B, Campbell BM. The Science of Sustainable Development: Local Livelihoods and the Global Environment. University Press; 2004.

[190] Nowotny H, Scott PB, Gibbons MT. Re-thinking Science: Knowledge and the Public in an Age of Uncertainty. John Wiley \& Sons; 2013. 
[191] Balvanera P, Daw TM, Gardner TA, Martín-López B, Norström $\mathrm{AV}$, Speranza Cl, et al. Key Features for More Successful Placebased Sustainability Research on Social-ecological Systems: A Programme on Ecosystem Change and Society (PECS) Perspective. Ecology and Society. 2017;22(1):14. doi:10.5751/ES-08826220114.

[192] Koschke L, Fürst C, Frank S, Makeschin F. A Multi-criteria Approach for an Integrated Land-cover-based Assessment of Ecosys- tem Services Provision to Support Landscape Planning. Ecological Indicators. 2012;21:54-66. doi:10.1016/j.ecolind.2011.12.010.

[193] Müller F, Burkhard B. The Indicator Side of Ecosystem Services. Ecosystem Services. 2012;1:26-30. doi:10.1016/..ecoser.2012.06.001.

[194] Manzini E. Design, When Everybody Designs: An Introduction to Design for Social Innovation. MIT Press: 